\title{
MYOID ANGIOENDOTHELIOMA OF THE SPLEEN - CASE REPORT AND LITERATURE REVIEW
}

Nikola Grubor ${ }^{1}$, Igor Ignjatovic ${ }^{1}$, Boris Tadic ${ }^{1}$, Marjan Micev ${ }^{1}$, Vladimir Milosavljevic ${ }^{2}$, Vladimir Djordjevic ${ }^{1}$, Djordje Knezevic ${ }^{1}$ and Slavko Matic ${ }^{1}$ ${ }^{1}$ University of Belgrade, Faculty of Medicine, Clinic for Digestive Surgery-First Surgical Clinic, Clinical Center of Serbia

${ }^{2}$ Department of General Surgery, General Hospital Stefan Visoki, Smederevska Palanka

\section{MIOIDNI ANGIOENDOTELIOM SLEZINE-} PRIKAZ SLUČAJA I PREGLED LIERATURE

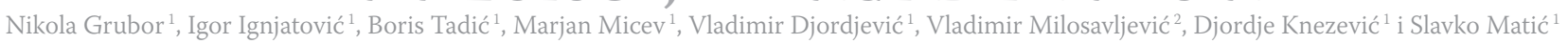
${ }^{1}$ Univerzitet u Beogradu, Medicinski fakultet, Klinika za digestivnu hirurgiju- Prva hirurška klinika, Klinički Centar Srbije ${ }^{2}$ Opšta bolnica "Stefan Visoki”, Smederevska Palanka

\begin{abstract}
Myoid angioendothelioma (MA) represents an extremely rare nonhaematopoietic proliferation of the spleen. $M A$ is a rare, benign, vascular tumour that consists of vascular elements and arranged stromal cells. Due to an absence of specific clinical signs and symptoms, MA is considered challenging to diagnose. Although the radiological presentation can indicate the vascular nature of the tumour, the diagnosis of MA is almost exclusively obtained from the use of histopathology after surgical excision and immunohistochemistry of the tissue. Due to its completely unclear biological behaviour and relationship with other primary and secondary tumours, the only effective therapy for $M A$ is splenectomy and a regular postoperative follow-up. Herein, we report a case of a 26-year-old male patient with nonspecific abdominal pain and a radiologically detected tumour of the spleen who underwent a laparoscopic splenectomy. Histopathologic and immunohistochemical examinations confirmed a myoid angioendothelioma of the spleen.
\end{abstract}

Keywords: myoid angioendothelioma, splenic tumour, immunohistochemistry, laparoscopic splenectomy.

\section{INTRODUCTION}

Myoid angioendothelioma (MA) of the spleen is uncommon and is a recently described entity that is classified as a type of nonhaematopoietic tumour of the spleen $(1,2,3)$. MA is a benign, vascular tumour of the spleen that is composed of vascular endothelial cells and stromal cells with myoid and myofibroblastic features. A contemporary immunohistochemical analysis enables the successful distinction of MA from other splenic vascular tumours, such as haemangiomas, angiosarcomas, lymphangiomas, littoral cell angiomas (LCA), haemangioendotheliomas and hamartomas (1,

\section{SAŽETAK}

Mioidni angioendoteliom (MA) slezine predstavlja veoma retku nehematološku proliferativnu promenu slezine. MA je redak, benigni, vaskularni tumor slezine koji se sastoji od vaskularnih elemenata i stromalnih ćelija. Zbog odsustva specifičnih kliničkih znakova i simptoma, dijagnotifikovati MA predstavlja izazov. Iako radiološka prezentacija može ukazati na vaskularnu prirodu tumora, dijagnoza MA se gotovo uvek dobija histopatološki i imunohistohemijom nakon operacije. Zbog potpuno nejasnog biološkog ponašanja $i$ odnosa sa drugim primarnim $i$ sekundarnim tumorima, jedina efikasna terapija za MA je splenektomija uz redovno postoperativno praćenje. Mi smo predstavili slučaj 26-to godišnjeg muškog pacijenta sa nespecifičnim bolom u abdomenu i radiološkim dijagnostifikovanim tumorom slezine kome je učinjena laparoskopska splenektomija. Histopatološkim $i$ imunohistohemijskim pregledom je potvrden mioidni angioendoteliom slezine.

Ključne reči: Mioidni angioendoteliom, tumor slezine, imunohistohemija, laparoskopska splenektomija.

2, 3). MA was first described by Kraus and Dehner in 1999, who documented 3 patients with this disorder (1). The disease occurs with an equal frequency in all age groups. Due to non-specific clinical presentations, MA is often accidentally discovered, which is similar to other vascular lesions of the spleen. According to the literature, after the radiological detection of a mass of an unclear origin in the spleen, patients underwent splenectomies, and the diagnosis of MA was obtained after histopathologic and immunohistochemical analyses of the extracted spleen $(1,2,3,4)$. 


\section{CASE REPORT}

A 26-year-old male patient was admitted to our hospital with a two-year history of intermittent abdominal pain in the epigastric and right subcostal regions. Previous medical and family histories revealed no prior malignancies or other significant comorbidities. The patient was a non-smoker and had not recently consumed beverages or illicit drugs.

Two years prior to admission, the patient underwent an oesophagogastroduodenoscopy, after which a hiatal hernia and signs of chronic Helicobacter pylori-negative gastroduodenitis were diagnosed. He was periodically treated with the use of proton pump inhibitors.

The laboratory findings and tumour markers were within reference ranges. An abdominal magnetic resonance imaging (MRI) scan revealed no splenomegaly $(12 \times 6$ $\mathrm{cm}$ ) and the presence of a solitary, well-circumscribed lesion $(28 \mathrm{~mm})$ in the lower pole of the spleen, with a peripheral rim enhancement on the arterial phase and a centripetal pattern of enhancement on the portal phase (Figure 1). The differential diagnosis included splenic tumours of different aetiologies, as well as a possible haemangioma of the spleen.

The patient received an operation that utilized a laparoscopic approach, and a splenectomy was performed. Intraoperatively, the splenic tumour, with a diameter of approximately $3 \mathrm{~cm}$, was observed in the lower pole. After the division of the ligamentar attachments and the complete mobilization of the spleen, a division of the hilar splenic vessels was performed with the use of an endoscopic stapler. The splenic specimen was placed in a large, plastic, impermeable bag and was retrieved through the umbilical port. Due to the fact that the tumour had to remain undamaged during the extraction process (in order to allow for a precise histopathological analysis), the intact spleen was carefully removed through the use of a mini-laparotomy that was created by the slight extension of the umbilical incision. The splenic specimen was fixed with $10 \%$ buffered formalin, and the representative sections were embedded in paraffin. The postoperative period was uneventful, and the patient was discharged on the fifth postoperative day.
After the histopathologic assessment, the microscopic findings revealed the presence of a well-circumscribed tumour that was composed of numerous capillary calibre vessels that were implanted in an eosinophilic matrix with pulp stromal cells (Figure 2-a; 2-b). Further immunohistochemical examinations revealed a strongly positive staining of the vascular lining cells for CD34 and CD31, while the stromal cells stained positive for SMA, desmin, actin and myosin SM (Figure 2-c; 2-d). Staining for S100, CD8 and CD21 were not present in either of the linings. Therefore, a diagnosis of myoid angioendothelioma of the spleen was confirmed. Regular postoperative check-ups after one, three, six and twelve months demonstrated that the patient was completely symptom free and lacked any other abdominal imaging disturbances.

\section{DISCUSSION}

The spleen, which is anatomically composed of red and white pulp, plays an important role in the complex modulation of the immune system by filtering the blood and recycling iron. The red pulp consists of a network of venous sinuses and Billroth cords, while the white pulp includes $\mathrm{T}$ and $\mathrm{B}$ lymphocytes. The imaging appearances of certain entities in the spleen, due to its complex structural morphology and function, can be deceiving and often cannot be distinguished with the utmost certainty $(6,7,8)$. The most common nonlymphoid tumours of the spleen originate from the vascular endothelium $(7,9)$. MA is an extremely rare, splenic, vascular tumour, with only 7 cases reported so far in the literature $(1,2,3,4)$. A proposed diagnostic algorithm for MA includes the use of preoperative multidetector computed tomography (MDCT), MRI and positron emission tomography-computed tomography (PET-CT) of the abdomen, as well as subsequent histopathological and immunohistochemical examinations, to determine the nature of the tumour cells $(2,3,4)$. A PET CT can reveal splenic myoid angioendothelioma as a hypermetabolic mass that has an increased uptake of fluorodeoxyglucose (FDG), which then indicates a neoplastic process (2).
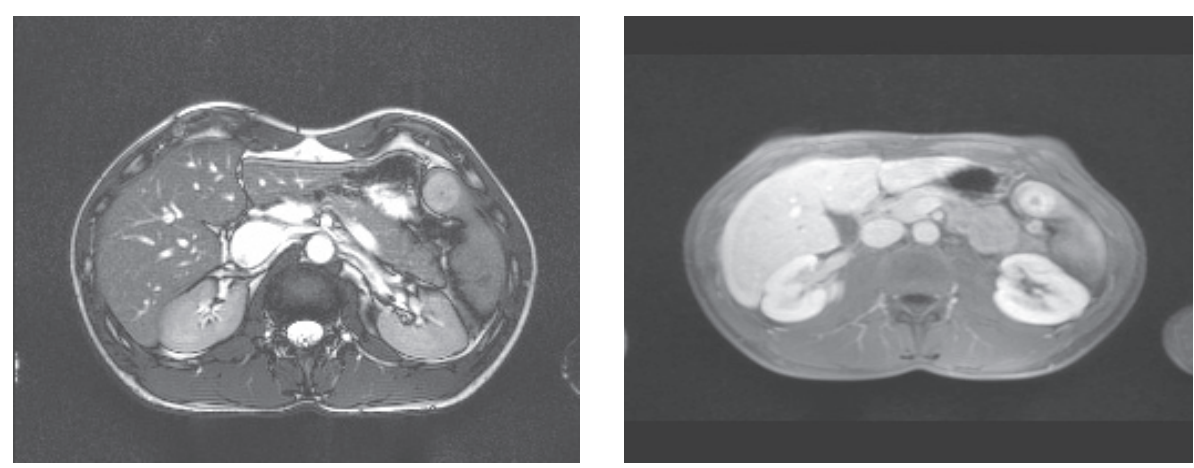

Figure 1: T1W and T2W axial abdominal MRI images

A solitary, well-circumscribed lesion $(28 \mathrm{~mm})$ in the lower pole of the spleen, with a peripheral rim enhancement on the arterial phase and a centripetal pattern of enhancement on the portal phase. 


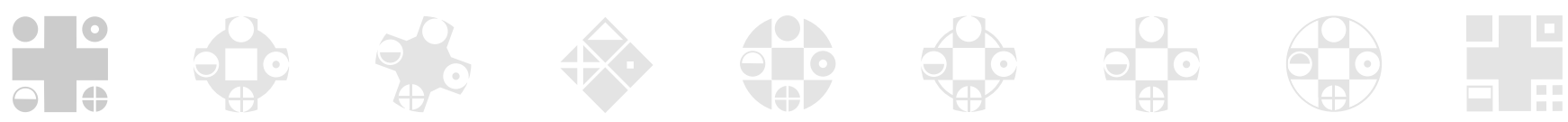
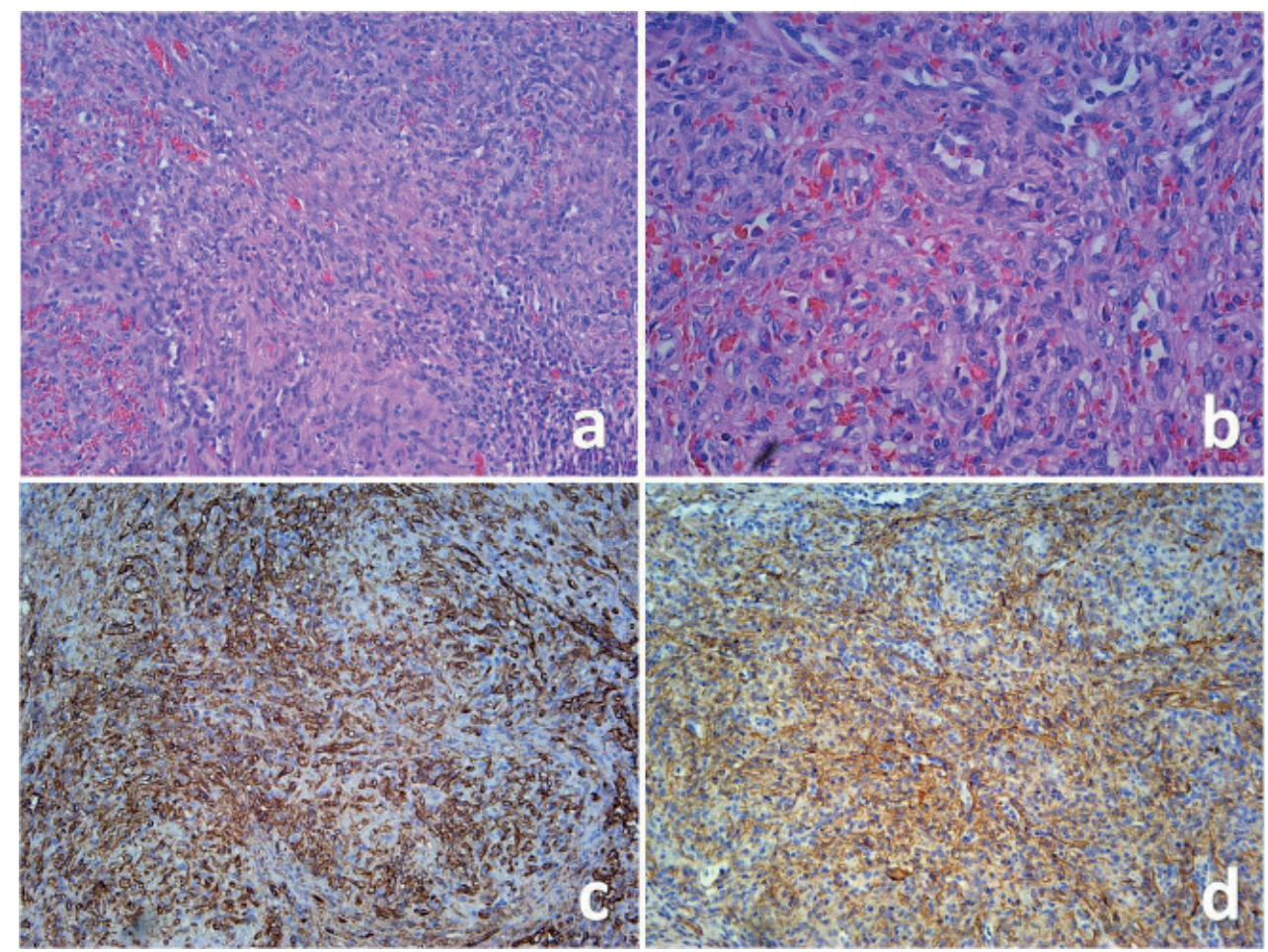

Figure 2: The histological presentation of a vascular tumour with characteristic compact proliferation of vascular and stromal elements. (a) Sieve-like, focally dilated vessels (b), which showed strong CD34 immunoexpression (c) accompanied by smooth muscle actin immunopositive stromal cells (d).

MDCT and MRI examinations usually describe MA as a round, well-circumscribed lesion, with a peripheral rim enhancement on the arterial phase and a centripetal pattern of enhancement on the portal phase, which can be attributed to the vascular nature of this disorder (2). The pathohistological findings of MA show a solid, wellcircumscribed tumour that contains numerous capillary calibre vessels that are embedded in the stromal cells of the pulp $[(2,3)$. The immunohistochemical findings reveal the strongly positive staining of stromal cells for SMA, CD31, CD34 and F VII, as well as negative staining for S100; additionally, the vascular lining cells stained positive for $C D$ 31 and CD34, and stained negative for CD8 $(2,3)$.

The first individuals to study myoid angioendothelioma were Kraus and Dehner in 1999, wherein they provided a description of a new, vascular tumour of the spleen by documenting 3 case reports (1). Splenomegaly was detected in only one patient who had a previous clinical presentation of abdominal pain. The other two cases were discovered by using ultrasound screening for Beckwith Wiedemann syndrome in one of the patients, and after a pancreatectomy, due to the incidence of a mucinous cystic pancreatic tumour, in the other patient. The tumour size did not exceed $4 \mathrm{~cm}$ in diameter in any of these patients (1). The immunohistochemical findings confirmed vascular cell lining positive staining for CD34 and F VIII, with variable reactivity for CD31, while the stromal cells were positive for SMA, MSA and desmin. The described phenotype indicated a vascular nature of the lining cells, while the SMA+ and
MSA+ polygonal cells represented the proliferation of the myoid lineage. Staining for S100, CD8 and CD21 was not seen in either of the linings (1). However, in 2004, Karim et al. reported a case of splenic MA in a 51-year-old male patient, with unexpected immunohistochemical findings of S100 positive cells in the stroma (3).

Despite the reported morphological and histological similarities to splenic epithelioid and spindled haemangioendothelioma, this immunophenotype enabled the differentiation of MA tumours of the spleen $(10,11,12)$. In 2013, Jang et al. described a case of rectal adenocarcinoma in a female patient with a radiologically registered metastatic disease in the liver and a splenic mass mimicking a metastasis. After a splenectomy, the pathohistological findings confirmed the diagnosis of MA, with immunochemical positive staining of the stromal cells for SMA and positive staining of the vascular channels for CD 34, CD31 and factor VIII (2). Chan et al. reported another case of splenic MA that was diagnosed in a child after a successful treatment of a Wilms' tumour of the kidney (4). Out of all of the reported cases of MA in the literature, even though 3 cases had previous malignant diseases, such as rectal adenocarcinoma, a pancreatic neoplasm and a Wilms' tumour, the biological behaviour of myoid angioendothelioma is still considered to be benign. All of these data suggest that further clinical and histopathological investigations should be performed and that patients should be closely monitored, due to a lack of precise biological behaviour of MA of the spleen. 


\section{CONCLUSION}

New cases of MA are expected to be reported in the future, as it is clearly defined as an independent morphological entity. Nevertheless, further research is needed for the evaluation of biological behaviour, the determination of aetiology, the clinical presentation, the pathohistology and the therapeutic options of splenic myoid angioendothelioma, due to its low incidence. Until recently, splenectomies were performed in all of the reported cases of MA patients, which present the only therapeutic options that are currently available. Furthermore, the association of MA with other neoplasms is uncertain, and further studies are necessary. All of the authors agree that the postoperative, regular follow-up of patients with MA is required.

\section{REFERENCES}

1. Kraus MD, Dehner LP. 1999. Benign vascular neoplasms of the spleen with myoid and angioendotheliomatous features. Histopathology;35(4):328-36.

2. Jang KY, Chung MJ, Moon WS, Sohn MH, Hwang SB, Lee MR, Lee H, Park HS. 2013. Myoid angioendothelioma of the spleen mimicking metastatic disease in a patient with rectal cancer: a radiologic-pathologic correlation. Ann Diagn Pathol;17(1):108-12.

3. Karim RZ, Ma-Wyatt J, Cox M, Scolyer RA. 2004. Myoid angioendothelioma of the spleen. Int J Surg Pathol;12(1):51-6.

4. Chan YF, Kumar B, Auldist A, Waters K. 2005. Myoid angioendothelioma of the spleen in a child after successful treatment of a Wilms' tumour. Pathology;37(2):181-4.
5. Pinkus GS, Warhol MJ, O'Connor EM, Etheridge CL, Fujiwara K. 1986. Immunohistochemical localization of smooth muscle myosin in human spleen, lymph node, and other lymphoid tissues. Unique staining patterns in splenic white pulp and sinuses, lymphoid follicles, and certain vasculature, with ultrastructural correlations. Am J Pathol;123(3):440-53

6. Ferrozzi F, Bova D, Draghi F, Garlaschi G. 1996. CT findings in primary vascular tumors of the spleen. AJR American Journal of Roentgenology;166(5): 1097-101.

7. Thipphavong S, Duigenan S, Schindera ST, Gee MS, Philips S. 2014. Nonneoplastic, benign, and malignant splenic diseases: cross-sectional imaging findings and rare disease entities. AJR Am J Roentgenol;203(2):315-22.

8. Karlo CA, Stolzmann P, Do RK, Alkadhi H. 2013. Computed tomography of the spleen: how to interpret the hypodense lesion. Insights Imaging;4(1):65-76.

9. Fotiadis C, Georgopoulos I, Stoidis C, Patapis P. 2009. Primary tumors of the spleen. Int J Biomed Sci;5(2):8591. Page 7 of 39 https://mc.manuscriptcentral.com/ eajm The Eurasian Journal of Medicine 12345678910 -60 For Review Only

10. Suster S. 1992. Epithelioid and spindle-cell hemangioendothelioma of the spleen. Report of a distinctive splenic vascular neoplasm of childhood. Am J Surg Pathol;16(8):785-92.

11. Requena L, Kutzner H. 2013. Hemangioendothelioma. Semin Diagn Pathol;30:29-44.

12. Zhendan wang, Liang Zhang,Bo Zhang,Dianbin $\mathrm{Mu}$, Kai Cui, Sheng Li. 2015.Hemangioendothelioma arising from the spleen: A case report and literature review Oncol Lett. 9(1): 209-212. 